Nadia Arfa Pratiwi, Zikri Alhadi I Kendala Pemerintah dalam Kegiatan Pelestarian Mangrove sebagai Sarana Pengurangan Resiko Bencana di Kota Pariaman

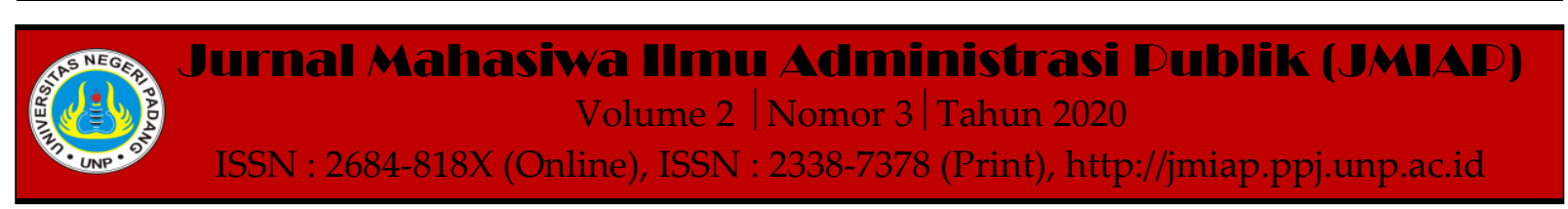

\title{
KENDALA PEMERINTAH DALAM KEGIATAN PELESTARIAN MANGROVE SEBAGAI SARANA PENGURANGAN RESIKO BENCANA DI KOTA PARIAMAN
}

\author{
Nadia Arfa Pratiwi'(a), Zikri Alhadi ${ }^{2(b)}$ \\ ${ }^{1}$ Jurusan Ilmu Administrasi Negara, Universitas Negeri Padang \\ ${ }^{2}$ Jurusan Ilmu Administrasi Negara, Universitas Negeri Padang \\ a)nadia.arfap@gmail.com, ${ }^{b}$ zikrialhadi@gmail.com
}

\begin{abstract}
The erticel is intends to determine the constraints and obstacles of the government in preserving mangroves as a means of disaster risk reduction in Kota Pariaman, mangroves have many benefits for the community, especially in disaster risk reduction in Kota Pariaman, but there are obstacles faced by the government in terms of mangrove conservation activities in the City. Pariaman, mangroves that grow around the coast in Kota Pariaman have been damaged by irresponsible persons, resulting in a reduction in mangrove forest land in Kota Pariaman even though Kota Pariaman is a city that has a fairly wide coastline and has a high level of disaster risk because it is a city. pariaman is located on the coast. This type of research is qualitative research using descriptive methods. Data collection techniques are carried out by means of interviews, observation and documentation studies, research instruments, namely the author himself, which the authors use, namely the interview guidelines that the author has prepared, the tools used in collecting data are cameras, cellphones, and voice recorders. For data collection using source triangulation. The results showed that there are several obstacles in mangrove conservation activities as a means of disaster risk reduction in Kota Pariaman, namely internal constraints, namely a lack of budget, lack of cooperation between the government and stakeholders who are both engaged in mangrove conservation, the external constraints are lack of public knowledge of the importance of mangrove forests for disaster risk reduction.
\end{abstract}

Keywords : Mangrove Conservation, Disaster Risk Reduction

Corresponding author. Email.nadia.arfap@gmail.com, zikrialhadi@gmail.com

How to cite this article. Pratiwi, N. Arfa \& Alhadi, Z. (2020). Kendala Pemerintah dalam Kegiatan Pelestarian Mangrove sebagai Sarana Pengurangan Resiko Bencana di Kota Pariaman. Jurnal Mahasiwa Ilmu Administrasi Publik (JMIAP) Jurusan Ilmu Administrasi Negara Fakultas Ilmu Sosial Universitas Negeri Padang, Volume 2 (3), Hal. 87-95.

http://jmiap.ppj.unp.ac.id

ISSN : 2684-818X (Online), ISSN : 2338-7378 (Print)

Copyright $\odot 2020$. Published by Labor Jurusan Ilmu Administrasi Negara FIS UNP, Padang 


\section{PENDAHULUAN}

Kota Pariaman memeiliki daerah pesisir yang sangat luas, dan memili empat buah pulau yaitu pulau kasiak, angso duo, pulau ujuang, dan pulau tangah, wilayah laut Kota Pariaman seluas $282,69 \mathrm{~km}$ persegi, luas daratan $73,53 \mathrm{~km}$ persegi panjang garis pantai sepanjang $12,7 \mathrm{~km}$, Kota Pariaman kaya akan keanekaragaman hayati yaitu salahsatunya hutan mangrove., dengan panjang garis pantai dan luas lautan yang di miliki Kota Pariaman, ini membuat Kota Pariaman rawan akan terjadinya bencana tsunami dan abrasi pantai, dan resiko dampak bencanannya juga cukup tinggi.

Upaya yang dapat dilakukan untuk meminimalisir dampak bencana yaitu membatasi wilayah permukiman di wilayah pesisir dan membuat area penyangga menggunakan pohon mangrove atau juga bisa pohon penyangga pantai seperti pohon cemara dan sejenis laniya, karena dampak dari kejadian bencana sering menimbulkan kerugian materi, dan jiwa itu disebabkan kuranya kewaspadaan masyarakat dan juga kesiapsiagaan untuk menghadapi bencana. Karena bencana yang rawan sekali terjadi di Indonesia adalah bencana gempa bumi yang disertai tsunami sehinnga membuat wilayah pesisir menjadi rusak.

Perlu manajemen bencana dalam penanggulangan kebencanaan, manajemen bencana disebut sebagai suatu bentuk serangkaian kegiatan yang pantas dan terstruktur, terpadu dan berkelanjutan yang dilaksanakan pada saat bencana sesudah ataoun sebelum bencana itu terjadi. Dalam manajemen bencana keikutsertaan masyarakat perlu dijaga dalam hal manajemen bencana walaupun sebenarnya yang bertanggung jawab penuh atas manajemen bencana adalah pemerintah pusat dan daerah tetapi keikut sertaan masyarakat perlu dijaga dan dikembangkan, karna kita akan melindungi lingkungan, ekonomi dan asset sosial dari adanya bencana tersebut. (Sadisun,2004).

Konsep pengurangan resiko bencana yaitu usaha meminimalisir dampat terjadinya suatu bencana maka dari itu perlu adanya strategi untuk mengurangi resiko dari terjadinya sebuah peristiwa bencana. Nurjanah dkk, (2013) menjelaskan pengurangan resiko bencana adalah suatu paradigma yang berfokus kepada analis resiko bencana, ancaman, kerentanan dan kemampuan masyarakat. Pramana (2008) menjelaskan paradigm pengurangan resiko bencana merupakan gabungan dari berbagai pandangan teknis dan ilmiah terhadap kondisi lingkungan, sosial, ekonomi dan politik. Teknik yang menggunakan analisis resiko bencana berdasarkan bahaya atau ancanaman serta kerentanan dalam meningkatkan kemapuan dalam mengurangi resiko dan manajemen bencana, serta menguranagi dampak bencana yang ditimbulkan, untuk melakukan manajeman bencana dilakukan bersama masyrakat pemangku kepentingan dan lintas sektor.

Tindakan yang dilakukan sebelum terjadi bencana yang bertujuan untuk mengurangi dampak dari bencana juga termasuk tindakan pengurangan resiko jangka panjang merupakan istilah dari mitigasi bencana. Penanganan bencana tidak hanyan semata bertindak pada saat pascabencana namun harus menggunakan strategi proaktif, yaitu dengan melakukan kegiatan untuk persiapan mengantisipasi kemungkinan terjadnya suatu bencana alam. Melakukan identifikasi kebutuhan, system peringatan secara dini, penyiapan anggaran, mengidentifikasi sumber sumber yang tersedia, alternative tindakan dan penyiapan anggaran serta koordinasi dengan pihak yang memantau perubahan alam, merupakan tindakan yang dilakukan untuk mengantisipasi datangnya bencana yang terjadi. Untuk mitigasi bencana dilakukan beberapa cara untuk meminimkan dampak dari bencana yang akan terjadi yaitu membuat program yang bertujuan dalam mengurangi penagruh dari adanya bencana terhadap komunitas atau masyarakat dilakukan melalui perencanaan tata ruang, pengaturan tataguna lahan, penyusunan peta kerentanan bencana, 
pemyusunan database, pemantuan dan pengembangan (djauhari,2014).

Salah satu upaya dalam mitigasi bencana sebelum terjadinya bencana ada dengan cara melestarikan hutan mangrove, menjaga dan malakukan rehabiliatasi hutan amngrive yang rusak. menurut Bengen (2001) dalam pelestarian hutan mangrove ada dua rancangan utama yang bisa diterapkan dalam peelstarian hutan mangrove, yang pertama rehabilitasi kawasan hutan mamgrove dan perlindungan terhadap hutan mangrove yang ada. Dengan cara menetapkan suatu kawasan hutan mamgrove menjadi suatu hutan konservasi dan menjadikan hutan mangrove sebagai bentuk sabuk hijau disepanjang pantai. Bentuk seperti ini sangat ampuh dilakukan untuk melestarikan kawasan hutan mangrove dan akan membawa hasil yang baik pula.

Maka perlu prestarian lingkungan salah satunya pelestarian hutan mangrove untuk mengurangi dampak dari adanya resiko bencana, pelestarian lingkungan merupakan usaha, menjag, memelihara, mencintai, dan memanfaatkan keberlangsungan untuk generasi mendatang. Menurut Boff dalam Bambang, 2013 terdapat beberapa prinsip pelestarian lingkungan yaitu:

1. prinsip keberlanjutan, pada prinsip ini menjadi landasan untuk memanfaatkan atau menebang alam secara rasional tanpa merusaknya.

2. Prinsip penghargaan dan pertahanan terhadap alam. Dalam prinsip ini dapat membantu manusia dalam melihat dan memahami nilai yang ada dalam semua ciptaan dan memebawa manusia itu sendiri bersikap penuh penghargaan dengan ciptaan yang lain, dengan cara memperlakukan organisme seperti tumbuh-tumbuhan dan binatang secara baik dan hati-hati.

3. Prinsip tanggung jawab, karena tanggung jawab adalah indikasi dari karakter dan etika manusi, maka dari itu manusia diharapkan untuk memperlakukan ciptaan tuhan dengan sewajarnya dan sebaik-baiknya.
Mangrove merupakan hutan pantai yang hidup mendominasi daerah pasang surut, sedangkan hutan bakau merupkan satu diantara jenis tumbuhan yang menata hutan mangrove itu sendiri. ( Zebua,2017) sedangkan menurut Bengen(2002) dalam Zebua 2017, menyatakan jenis pohon yang mampu tumbuh dan berkembang pada kawasan pasang surut pantai yang berlumpur merupakan komunitas vegetasi pantai tropis dan subtropis yaitu pohon mangrove yang merupakan yang dapat tumbuh dan berkembang didaerah pasang surut pantai yang berlumpur. Biasanya hutan manrove banyak dijumpai di pantai teluk yang dangkal, mulut sungai, muara sungai, dan daerah yang dilindungi.

Jika kawasan pesisir tertutup oleh adanya hutan mangrove maka ekosistem yang ada pada kawasan pesisir akan lebih stabil. Masalah pada lingkungan yang timbul pada daerah pesisir yang mana hutan mangrovenya dirusak oleh manusia maupun akibat kegiatan lain yang secara ekologis dapat menimbulkan abrasi dan kelongsoran pantai. Kerugianya sangat komplek, meliputi aspek ekonomi, social, dan ekologi. kajadian ini membuktikan bahwa rusaknya kawasan hutan mangrove bukan cuma berdampak pada menurunya kemapuan hutan mangrove dalam menahan gelombang tsunami dan abrasi, tetapi juga berdampak kepada ekosistem laut maupun ekosistem darat. menimbang sangat pentingnya fungsi hutan mangrove dalam melindungi komponen wilayah peisisir ataupun laut. Dengan demikian program pelestarian mangrove perlu di perhatikan dan di perioritaskan.

Hutan mangrove di kota pariaman paling luas di kecamatan pariaman utara, sedangkan di kecamatan pariaman selatan dan kecamatan pariaman tengah memiliki luas hutan mangrove yang lebih sediki. Penurunan luasan hutan mangrove akan memberikan dampak yang kurang baik, terutama pemukiman penduduk yang ada di wilayah pesisir. Wilayah pesisir kota pariaman memiliki tingkat kerentanan fisik yang sangat tinggi. Kondisi ini di sebabkan 
karena terdapatnya kondentrasi pemukiman yang dekat dengan garis pantai, kemiringan pantai yang landai serta tingkat abrasi yang cukup tinggi, ramadhan dan abdillah, ( dalam navisah devi,dkk, 2019).

Fungsi hutan mangrove dalam melindungi serta melestarikan kawasan pesisir dapat dilihat secara ekologis yaitu,

1. Dapat melindungi kehidupan dibelakang garis pantai dari gelembang tsunami, abrasi dan angin, serta mencegah terjadinya salinisasi pada wilayah yang ada dibelakngnya, karena keadaan akarnya yang kuat serta rapat mampu menggenggan dan menstabilkan habitat tumbuhnya, dan keadaan tajuk yang relative rapat

2. Karena sistem akarnya yang dapat menahan lumpur sungai dan menyerap berbagai bahan pollutan, sehingga dapat melindungi padang lamun dan juga terumbu karang yang secara ekologis akan dapat pada akhirnya melindungi kehidupan berbagai jenis flora dan fauna yang beradaptasi dengan padang lamun dan terumbu karang.

3. Banyak manusia yang membutuhkan mangrove sebagai mata pencariannya, seperti mencari ikan kecil, udang, kepiting, maupun dimanfaatkan sebagai bahan untuk obat-obatan, selain itu melindungi tempat buaya dan berlindungnya berbagai jenis udang komersial, ikan-ikan, dan juga termasuk melindungi tempat tinggal baik tetap maupun sementara berbagai jenis burung-burung, mamalia, kepiting, ika,udang dan reptile, yang paling banyak diantaranya termasuk jenis binatang yang di lindungi.

Berdasarkan data yang di peroleh dari badan pusat statistik kota pariaman (2009), diketahui bahwa pada tahun 2004 luas hutan mangrove di kota pariaman yaitu 5ha, lalu meningkat pada tahun 2006 menjadi $20 \mathrm{Ha}$. Pada tahun 2009 terjadi penurunan lagi menjadi menjadi $17,75 \mathrm{Ha}$, sedangkan pada tahun 2012 menjadi 18 Ha. Fluktuasi ini disebabkan karena degredasi pada ekosistem mangrove yang dapatt dilihat dengan adanya kematian pohon mangrove. Alih funsi lahan menjadi perkebunan kelapa sawit, infrastruktur, pemukiman dan pembangunan gedung sekolah juga mengakibatkan penurunan ekosistem hutan mangrove.

Hingga sampai sekarang pada tahun 2018 hutan mangrove juga terjadi pengurangan lahan akibat pembabatan hutan yang dilakukan oleh oknum DPR untuk pembukaan jalan, pembabatan hutan mangrove terjadi di kecamatan pariaman utara yang mana luas hutan mangrove di kecamatan tersebut lebih luas dari kecamatan lain yang ada dikota pariaman, hutan mangrove yang di babat tersebut rencananya akan di jadikan akses jalan dari desa ampalu sampai ke desa mangguang, untuk rencana pembuatan jalan tersebut hutan mangrove yang telah dirusak sekitaran kurah lebih $1 \mathrm{Ha}$.

Tanpa sepengatahuan pemerintah dan dinas terkait masyarakat telah membabat sekitaran satu kilo meter hutan mangrove dengan alat berat, setelah dilakukannya perusakan hutan mangrove tersebut yang menghabiskan sekitaran 5000 batang pohon mangrove menggunakan eskavator, pemerintah menghentikan proyek di kawasan konservesi ini dengan memasang garis polisi, karena perusakan hutan mangrove tersebut telah melanggar hukum.

Dalam rangka perlindungan dan pemanfaatan sumber daya kelautan yang optimal Dinas Kelautan Provinsi Sumatera Barat melaksanakan program pengelolaan kawasan konservasi di wilayah pesisir Sumatera Barat. Terkait pelestarian mangrove untuk penguranagan resiko bencana di Kota Pariaman terdapat dua kegiatan, yaitu penyiapan masyarakat pesisir terhadap bencana dan rehabilitasi mangrove. Namun pada pelaksanaan kegiatan tersebut terdapat Kendal-kendala yang di hadapi oleh DKP dalam pelestarian mangrove untuk pengurangan resiko bencana di Kota pariaman. 
Maka dari itu dalam pelaksanaan kegiatan pelestarian mangrove sebagai sarana pengurangan resiko bencana di Kota Pariaman perlu kerjasama, komunikasi yang baik serta koordinasi antar stakeholder, serta komunikasi yang baik agar pelestarian mangrove sebagai sarana pemgurangan resiko bencana di Kota Pariaman dapat berjalan dengan optimal, serta memberikan pemahaman kepada masyarakat setempat akan pentingnya hutan mangrove untuk mengurangi dampak dari resiko bencana itu sendiri, sehingga DKP Sumbar dengan stakeholder yang samasama bergerak di bidang pelestarian mangrove sebagai sarana penguranagn resiko bencana dapat mencapai tujuannya dengan baik sesuai apa yang di inginkan.

\section{TINJAUAN PUSTAKA \\ Teori Kendala}

Factor yang menghalangi ataupun menhambat yang dihadapi oleh instansi baik itu secara internal dan juga eksternal merupakan bentuk dari suatu kendala. Yang membatasi system, baik instansi maupun organisasi dalam mencapai suatu tujuan dari instansi itu sendiri juga disebut dengan kendala. Dalam pelestarian mangrove sebagai sarana penguranagan resiko benacana di Kota Pariaman ada beberapa kendala yang dihadapi oleh DKP Sumbar dalam melakukan kegiatan pelestarian mangrove untuk pengurangan resiko bencana di Kota Pariaman, maka kendala yang di hadapi perlu ditangani agar pelestarian mengrove untuk pengurangan resiko bencana dapat dilakukan secara efektif. Agar tidak ada lagi penghamabat dalam melakukan kegiatan pelestarian mangrove di Kota Pariaman.

Cox dan Scheiler dalam Selviana dan Setya (2016:268) juga mengatakan Theory Of Constrains yang lebih terkenal juga dengan sebutan TOC. TOC juga dapat di artikan sebagai sebuah pendekataan yang lebih menunjukan pada arah peningkatansuatu proses yang lebih difokus terhadap elemen-elemen yang dapat menghambat kinerjanya yang akan dilakukan oleh suatu instansi atau organisasi dalam meningkatkan outputnya.

Hansen dan Mowen dalam Selviana\&Setya(2016:23)menggolongkan berbagai macam kendala yang sudah terbagi menjadi kendala internal dan kendal ekstenal ialah sebagai berikut:

1) Kendala internal

Kendala internal merupakan kendala yang menjadi faktor penghambat yang berasal hanya didalam instansi itu sendiri. Kendala yang di temukan dalam pelestarian mangrove sebagai sarana penguranagn resiko bencana di Kota Pariaman merupakan suatu kendala yang asalnya dari dalam instansi.

2) Kendala Eksternal

Kendala eksternal ialah suatu kendala yang juga berasal dari luar organisasi. Dalam kegiatan pelestarian mangrove sebagai sarana penguran resiko bencana di Kota Pariaman kendala yang terjadi dapat dikatakan berasal luar organisasi pemerintah.

\section{Pelestarian Mangrove}

Dalam melakukan kegiatan pelestarian hutan mangrove, yang dijelaskan oleh Benge (2001) ada dua garis besar yang diterapkan, yaitu rehabilitasi hutan mangrove yang rusak dan juga perlindungan hutan mangrove. Dengan menjadikan kawasan hutan mangrove sebgaai kawasan konservasi dan membentuk sabuk hijau disepanjang pantai , merupakan beberapa cara yang dilakukan dalam rangka perlindungan terhadap keberadaan hutan manmgrove. Namun dalam perlindungan hutan mangrove di Kota Pariaman masih terjadi kendala yang mengakibatkan tidak efektifnya pelestarian mangrove sebagai sarana pengurangan resiko bencana di Kota Pariaman, buktinya masih terjadi perusakan hutan mangrove, masih belum dilakukannya rehabilitasi hutan mangrove oleh DKP Sumbar pasca perusakan hutan mangrove sampai sekarang. 


\section{Penelitian Relevan}

Penelitian yang dengan penelitian yang dilakukan oleh peneliti yaitu penelitian dengan judul "Komunitas Mangrove dalam Pengurangan Resiko Bencana" Putra Agina, Sarwono, Podo Yuwono (2019) tujuan penelitian ini adalan melihat bagaimana tatakelola arekosistem mangrove dan regulasi pemerintah dalam perawatan, serta peran komunitas wonamangrove muhammadiyah dalam pelestarian ekosistem mangrove. Komunitas mangrove muhammadiyah menjadi bagian dari instansi dan pengelolaan ekosistem mangrove dengan melibatkan masyarakat dan dan melakukaan koordinasi dengan BPBD. Persamaan yang peneliti teliti yaitu menelitimelihat bagaimana tatakelola hutan mangrove yang dilakukan ole pemerintah bekerja sama dengan komunitas dan berkoordinasi dengan $\mathrm{BPBD}$, perbedaan yang diteliti yaitu pada penelitian ini meneliti bagaimana peran pemerintah, komunitas dan lembaga dalam mengelola mangrove sebagais eran pengurangan resiko bencana, sedangkan yang diteliti oleh peneliti yaitu apa saja kendala yang dihadapi pemerintah dalam melakukan pelestarian mangrove sebagai sarana pengurangan resiko bencana di Kota Pariaman. Penelitian yang relevan lainya yaitu berjudul "Pelestarian Hutan Mangrove Berbasis Masyarakat dan Strategi Pengurangan Resiko Bencana di Kampung Apainabo Distrik Urei Fasei Kab. Waropen Papua" Mareyana Trianne Zebua (2017) maksud dalam penelitian ini adalah melihat kegiatan pengelolaan hutan mangrove berbasis masyarakat pada Kampung Apainabo untuk meningkatkan kesejahteraan dan perlindangan bagi masyarakat sekitaran hutan mangrove lewat kegitan pelestarian hutan mangrove. Adapun persamaan pada penelitian ini yaitu sama-sama melihat bagaimana pelestarian mangrove untuk pengurangan resiko bencana, sedangkan perbedaan pada penelitian ini yaitu pada penelitian ini mengkaji tentang bagaimana masyarakat dalam melakukan pelestarian mangrove dan pengelolaan mangrove di Kampung Apainabo, sedangkan yang diteliti oleh peneliti yaitu apa saja kendala yang dialami oleh pemerintah dalam melaksanakan kegiatan pelestarian mangrove sebagai sarana pengurangan resiko bencana di Kota Pariaman.penelitian relevan selanjutnya adalah berjudul "Persepsi Masyarakat terhadap fungsi Hutan Mangrove Dalam Upaya Pengurangan Resiko Bencana" Said Khairul, Indra, Eldina Fatimah ( 2016 ) penelitian ini bertujuan untuk mengukur persepsi masyarakat mengenai hutan mangrove, fungsi hutan mangrove dan kegunaan hutan mangrove, pada penelitian ini sudah banyak masyarakat mengetahui apa fungsi dan kegunaan dari hutan mangrove untuk mevegah abrasi pantai, menyangga kelestarian ekosistem mangrove dan juga melindungi masyarakat dari adanya bencana apabila terjadi bencana. Adapun dalam penelitian ini persamaanya yaitu sama-sama meneliti kegunaan mangrove untuk pengurangan resiko bencan, sedangkan perbedaan pada penelitian ini yaitu penelitian ini mengkaji bagaimana pengetahuan masyarakat persepi masyarakat, tentang fungsi hutan mangrove, sedangkan penelitian yang akan peneliti teliti berfokus kepada kendala apa saja yang membuat pelestraian mangrove sebagai saran pengurangan resiko bencana di Kota Pariaman tidak efektif.

\section{METODE PENELITIAN}

Penelitian ini menggunakan pendekatan kualitatif dengan memakai metode, dapat dikatakan demikian karena penelitian ini berupaya mendeskripsikan suatu gejala, peristiwa, kejadian yang berlangsung dilapangan secara apaadanya. Bodgan dan Taylor dalam Barowi (2008:21). Menjelaskan penelitian kualitatif merupakan siasat penelitian yang menghasilkan data deskriptif berupa katakata tertulis atau lisan dari berbagai orang dan perilaku yang diamati. Krik dan Miler dalam Basrowi (2008:21). Mengatakan bahwa metodelogi kualitatif adalah 
kebiasaan tertentu dalam ilmu pengetahuan sosial yang secara mendasar berpegangan pada pengamatan manusia dalam kawasanya sendiri dan berhubungan dengan berbagai orang tersebut dalam bahasanya dan dalam peristilahannya. Untuk teknik pengumpulan data yang penulis pakai dalam pengumpulan data yaitu teknik wawancara, observasi dan studi dokumnetasi. Bnerdasarkan judul penelitian tersebut, maka lokasi penelitian dilakukan di Dinas Kelautan dan Perikanan Provinsi Sumatera Barat, BPBD Kota Pariaman, Komunitas TDC, Pakar Lingkungan dan Masyarakat yang berada di daerah pesisir Kota Pariaman. Dalam melakukan uji keabsahan data peneliti memakai suatu teknik yang dinamakan dengan triangulasi sumber. Sedangkan dalam teknik analisis data yang peneliti pakai adalah dengan cara mereduksi data, melakukan penyajian data, dan melakukan verifikasi data

\section{HASIL DAN PEMBAHASAN}

Kendala dalam pelestarian mangrove untuk pengurangan resiko bencana di Kota Pariaman

Kendala merupakan faktor yang menghalangi atau mecegah pencapaian tujuan dalam melaksanakan suatu kegiatan baik itu pelaksanaan dari dalam maupun dari luar pelaksanaan. Berdasarkan temuan penelitian hambatan pelstarian mangrove di Kota Pariaman untuk pengurangan resiko bencana mengalami beberapa kendala/hambatan dalam pelaksanaannya. Hambatan ini terdiri dari hambatan Internal dan Hambatan Ekternal (Hansen dan Mowen: 2007 dalam Haksama:2016) sebagai berikut:

\section{a) Internal}

Kendala yang terjadi di dalam lingkungan internal di penelitian ini yaitu kurangnya kerjasama yang baik dalam pelaksanaan kegiatan pelestarian mangrove sebagai sarana penguranagn resiko bencana di Kota Pariaman, serta kurangnya koordinasi dan pengawasan dalam pelestarian mangrove sebagai saran pengurangan resiko bencan di Kota Pariaman sehingga masih terjadi pembabatan dan perusakan hutan mangrovedi Kota Pariaman, serta kurangnya anggaran untuk pelaksanaan kegiatan rehabilitasi mangrove sehingga pelestarian mangrove sebagai sarana pengurangan resiko bencana tidak optimal dan kegiatan tidak bisa terlaksana sesuai yang diharapkan.

Hambatan internal menurut Hansen dan Mowen: 2007 dalam Haksama:2016 faktorfaktor yang membatasi perusahaan pada dasarnya berasal dari dalam perusahaan, seperti keterbatasan jam mesin. Untuk meningkatkan tingkat produksi semaksimal mungkin tanpa meningkatkan persediaan dan biaya operasional, Adalah dengan cara memanfaatkan kendala internal dengan optimal.

Jadi, berdasarkan teori tersebut dapat disimpulkan bahwa hambatan/kendala internal yang berasal dari dalam pelaksanaan kegiatan pelestarian hutan mangrove di Kota Pariaman untuk penguranagn resiko bencana yaitu terletak pada kurangnyapengawasan dan koordinasi yang baik antara DKP Sumbar dengan instansi dan lembaga yang sama-sama begerak dalam pelestarian mangrove sebagai sarana penguranagn resiko bencana di Kota Pariaman.

\section{b) Ekternal}

Kendala ekternal bukan cuma terjadi pada pelaksana kebijakan akan tetapi juga pada kelompok sasaran kebijakan. Kendala itu yaitu berupa kesadaran dari kelompok sasaran dalam menerapkan program dari pelaksanaan kebijakan. Masih kurangnya partisispasi masyarakat dalam pelestarian hutan mangrove sebagai sarana pengurangan resiko bencan di Kota Pariaman, ketidak pedulian masyarakat terhadap keberlangsungan hidup ekosistem mangrove yang ada di Kota Pariamanakibatnya masih terjadi perusakan hutan mangrove oleh masyarakat sehingga membuat hutan mangrove yang ada di sekitaran pesisir Kota Pariaman tidak 
efektif lagi sebagai sarana pengurangan resiko bencana, karena jumlah lahan hutan mangrove telah berkurang dan juga pembangunan fisik yang dilakukan di sekititaran lahan hutan mangrove yang mengakibatkan pelestarian dan kehidupan mangrove terganggu.

Hambatan eksternal menurut Hansen dan Mowen berdasarkan asalnya yaitu komponen-komponen yang menghambat perusahaan yang berawal dari luar perusahaan, seperti permintaan pasar atau jumlah bahan mentah yang disediakan dari distributor. Kendala eksternal yang berbentuk kapasitas produk yang bisa dijual, dapat dicapai dengan menemukan pasar, menaikan permintaan pasar atau juga dengan mengolaborasikan produk baru.

Jadi, berlandaskan teori dapat disimpulkan bahwa faktor-faktor yang membatasi pelaksanaan kegiatan yang berasal dai luar yaitu seperti kurangnya partisipasi dan ketidak pedulian masyarakat terhadap pentingnya hutan mangrove sebagai sarana pengurangan resiko bencana sehingga masih terjadi perusakan hutan mangrove oleh masyarakat itu sendiri di tandai dengan peristiwa pembabatan yang dilakukaoleh masyarakat membuktikan masyarakat yang ada di sekitaran hutan mangrove tidak peduli akan pelestarian mangrove dan kurangya partisipasi dalam pelestarian mangrove di Kota Paraiaman, dan juga kendala ekternal yang mengambat pelestarian mangrove di Kota Pariaman dikarenakan pemabangunan fisik yang dilakukan di sekitaran hutan mangrove di Kota Pariaman, di buktikan dengan pemindahan pohon mangrove oleh masyarakat sekitaran hutan mangrove karena akan di bangun pagar beton pembuatan lapangan bola di dekat lahan hutan mangrove yang ada di Kota Pariaman.

\section{PENUTUP}

Kendala dalam pelestarian mangrove di Kota Pariaman untuk pengurangan resiko bencana.Kendala adalah suatu aspek yang menjadi penghalang terlaksananya pelaksanaan baik dari luar maupun dari dalam. Kendala ini merupakan hambatan dari dalam dan luar atau juga disebut kendala internal dan ekternal. Dalam kegiatan pelestarian mangrove kendala yang sering terjadi di Kota Pariaman untuk pengurangan resiko bencana yaitu kurangnya kerjasama dan koordinasi serta pengawasan hutan mangrove di Kota Pariaman yang dilakukan oleh DKP Sumbar dan stake holder yang sama-sama bergerak dalam kegiatan pelestraian mangrove untuk pengurangan rrsiko bencana, dan juga anggaran untuk rehabilitiasi hutan mangrove yang telah rusak dan punah juga tidak ada sehingga pelestarian mangrove sebagai sarana pengurangan resiko bencana tidak optimal dan kegiatan tidak bisa terlaksana sesuai yang diharapkan. Dikarenakan kendala internal yang terjadi dalam kegiatan pelestarian mangrove untuk penguranagn resiko bencana di Kota Pariaman Kendala ekternal yang terjadi dalam pelaksanaan kegiatan pelestarian hutan mangrove sebagai sarana penguranagn resiko bencana di Kota Pariaman yaitu kurangnya partisipasi dan ketidak pedulian masyarakat terhadap pentingnya hutan mangrove sebagai sarana pengurangan resiko bencana sehingga masih terjadi perusakan hutan mangrove oleh masyarakat itu sendiri. Dibuktikan dengan semakin berkurangnya luas lahan hutan mangrove yang ada di Kota Pariaman sampai sekarang, dan belum ada rehabilitasi dilakukan DKP Sumbar, dan juga kendala eksternal juga terjadi karena pembangunan fisik yang terjadi di Kota Pariaman yamg mengakibatkan terganggunya pelestarian hutan mangrove di Kota Pariaman.

\section{DAFTAR KEPUSTAKAAN}

Basrowi dan suwandi. 2008. Memahami penelitian kualitatif. Jakarta: Rineka Cipta.

Bengen Dietriech. G. 2001. Pengenalan dan Pengelolaan Ekosistem Mangrove. 
Nadia Arfa Pratiwi, Zikri Alhadil Kendala Pemerintah dalam Kegiatan Pelestarian Mangrove sebagai Sarana Pengurangan Resiko Bencana di Kota Pariaman

PKSPL-IPB, Bogor.

Erimi Karminarsih, 2007. Pemanfaatan Ekosistem Mangrove bagi Minimasi Dampak Bencana di Wilayah Pesisir.Volume XIII. No. 3 Desember 2007.

Imam A. sadisun, 2004. Manajemen Bencana: Starategi Hidup di Wilayah Berpotensi Bencana

Kusno Wibowo, Titin Handayani, 2006. Pelestarian Hutan Mangrove Melalui Pemdekatan Mina Hutan (silvofishery). Volume. 7. No. 3, September 2006.

Mereyan Trianne Zebua, 2017.Pelestarian Hutan Mangrove Berbasis Masyarakat Dan Strategi Pengurangan Risiko Bencana di Kampung Apainabo Distrik Urei Fasei Kab. Waropen - Papua. Volume 6. No. 1 Juni 2017.

Moleong, J. Lexy. 2013.Metode Penelitian Kualitatif. Bandung: PT Rosdakarya.

Noor, Djauhari, 2014. Pengantar Mitigasi Bencana Geologi. Yogyakarta: CV Budi Utama.

Nurjanah, R. sugiharto, Dede Kuswanda, Siswanto BP, Adikoesomo, 2013. Manajemen Bencana. Bandung: Alfabeta.

Podo Yuwono,Dkk, 2019. Komunitas Mangrove Dalam Pengurangan Resiko Bencana. Volume 1 No. 2 Desember 2019.

Said Khairullah,dkk, 2016. Presepsi Masyarakat Terhadap Fungsi Hutan Mangrove Dalam Upaya Pengurangan Resiko Bencana. Volume 3, No. 3, Agustus 2016.

Selviana Putri Lara Sati dan Setya Haksama. Penerapan Theory Of Constraint Pada Kepuasan Kerja Karyawan Sakit Mata Undaan
Surabaya. Jurnal Administrasi Kesehatan Indonesia Volume. 4. No. 2, Juli-Desember 2016.

Selviana Putri Larasati, Setya Haksama. 2016. Penerapan Theory of Constraint Pada Kepuasan Kerja Karyawan Rumah Sakit Mata Undaan Surabaya. Jurnal Administrasi Kesehatan Indonesia Vol. 4 No. 2

Sugiyono, 2017.Metode Penelitian Kuantitatif, Kualitatif, Kombinas. Bandung: Alvabeta. 